\title{
Szúcs Kinga
}

\section{A teológiai gondolkodás lehetőségei egy ökológiai szemléletű táplálkozásetikában}

\author{
Kinga Szűcs:
}

The Perspectives of Theological Thinking in Ecologically Driven Food Consumption Ethics

\begin{abstract}
Summary
Analysis of the complex environmental effects of food production and consumption points to the need of examining the ethical side of these issues. The study is is looking for possible answers to the questions 1.) what connections theology and theological ethics have to the current ecological crisis in a historic perspective, 2.) what emphasis eating, food production and consumption receive in ecotheological ethics, and 3.) whether contemporary theology is able to offer approaches which are acceptable and inspiring for audiences from a wider ecoethical background.
\end{abstract}

Keywords: theological ethics, ecological crisis, ecotheology, food production and consumption

\section{ÖSSZEFOGLALÓ}

Az élelem-előállítás és az élelmiszer-fogyasztási szokások összetett környezeti hatásait vizsgálva jól kirajzolódik az etikai jellegű kérdésfelvetés szükségessége. Az alábbiakban arra keresünk lehetséges válaszokat, hogy egyrészt történeti perspektívában mi köze lehet a teológiának és a teológiai etikának az ökológiai krízishez, másrészt milyen sajátos hangsúlyt kapnak a táplálkozással, élelmiszer-előállítással és élelmiszerfogyasztással kapcsolatos kérdések egy ökoteológiai alapozású etikában, s végül vajon kínál-e más ökoetikai elgondolásoktól különböző, ugyanakkor szélesebb kör számára is ösztönző, megismerésre méltó megközelítésmódokat a kortárs teológia.

Kulcsszavak: teológiai etika, ökológiai krízis, ökoteológia, élelmiszer-termelés és fogyasztás

Első pillantásra talán magyarázatra szorul, hogyan kapcsolódik össze a táplálkozás hétköznapi gyakorlata a teológiai etikával. Ha azonban az élelem-előállítás és az élelmiszer-fogyasztási szokások összetett környezeti hatásai felől közelítünk, rögtön kézzelfoghatóbbá válik az etikai jellegű kérdésfelvetés megalapozottsága. Az alábbiakban arra keresünk lehetséges válaszokat, hogy egyrészt történeti perspektívában mi köze lehet a teológiának és a teológiai etikának az ökológiai krízishez, másrészt milyen sajátos hangsúlyt kapnak a táplálkozással, élelmiszer-előállítással és élelmiszerfogyasztással kapcsolatos kérdések egy ökoteológiai alapozású etikában, s végül vajon kínál-e más ökoetikai elgondolásoktól különböző, ugyanakkor szélesebb kör számára is ösztönző, megismerésre méltó megközelítésmódokat a kortárs teológia.

A táplálkozás mint alapvető emberi szükségletkielégítés az élet szinte minden területére hatással van, az egyén testi egészségére éppúgy, mint a társadalmi, gazdasági és politikai struktúrák állapotára és alakulására. Napjainkra nyilvánvalóvá vált, hogy az emberi tevékenység, azon belül is kitüntetett helyen az élelmiszerelőállítás a természeti környezet irreverzibilis megváltozásához, az esetek jelentős részében egyértelműen kimutatható károsodásához vezet. (Gondolhatunk itt sok egyéb mellett a termőterületek növelése érdekében végrehajtott erdőirtásra, a mútrágyázásra, a génmódosított növények termesztésének összetett prob- 
lematikájára, a túllegeltetésre, a túlhalászatra, az állatok által kibocsátott üvegházhatású gázok problémájára, az állati ürülék és az állatfeldolgozás során keletkező egyéb szerves hulladékok elhelyezésének és ártalmatlanításának gondjára, valamint az egészségtelen körülmények között tartott állatok túlgyógyszerezésére, ill. az ipari húsfeldolgozás mechanizmusában rejlő állandó fertőzésveszélyre).

A káros környezeti hatásokon túl társadalmi tényezőkkel is számolni kell. A Föld gyors ütemben szaporodó népességének élelmiszer-igénye is folyamatosan növekszik, s e növekedés mellett a táplálkozási szokások megváltozásával is számot kell vetni. Azok a hagyományosan elsősorban növényi diétát követő társadalmak, amelyekben legrohamosabban nő a népesség, a globális információáramlásnak köszönhetően új táplálkozási mintákat kezdenek követni, mégpedig a nyugati világ húst és finomított élelmiszereket fogyasztó táplálkozási szokásait. A hús és a feldolgozott élelmiszerek előállítása azonban a gabona- és zöldségtermesztésnél jóval nagyobb környezeti terhelés árán valósulhat csak meg. Ráadásul a nyugati világ hús iránti igényét sem kizárólag a helyben termelt javak elégítik $\mathrm{ki}$, a vágóállat-tenyésztés és a takarmánytermesztés is egyre nagyobb mértékben helyeződik át a harmadik világ országaiba, az élelmiszeripar okozta környezeti ártalmak jelentős része pedig elsődlegesen ezen országok lakóit érinti, miközben az előállítók nem vagy csak alig részesednek az általuk elóállított termékek ellenértékéből. Nem feledkezhetünk meg továbbá a mezőgazdaságban és a húsiparban dolgozó munkások az ipari forradalom nyomorát idéző munkakörülményeiről - arról, hogy a képzetlen munkaerő kiszolgáltatottságát hogyan használja ki az ágazat.

Ha ezeket a világméretű gondokat a teológia szemszögéből vizsgáljuk, érdemesnek látszik elgondolkodni azon, hogy a nyugati világ étkezéssel kapcsolatos hagyományai mennyiben befolyásolják mai táplálkozási szokásainkat, és az évszázadok alatt rögzült képzetek mennyiben lehetnek felelősek a kedvezőtlen változásokért. Különösen éles perspektívába helyezi a keresztény felelősség kérdését Lynn White sokat idézett 1967-es cikke, amely a zsidó-keresztény alapokon nyugvó nyugati kultúra antropocentrikus szemléletét hibáztatja korunk globális válságáért. „Mivel mind a tudomány, mind a technika korunk szent szavai közé tartoznak, egyeseknek kedvére lehet az, hogy egyrészt történetileg a természettudomány nem más, mint a természeti teológia bizonyos meghoszszabbítása, másrészt, hogy a modern technika legalább részben értelmezhető úgy, mint az ember természetre vonatkoztatott transzcendenciája és a természet fölött jog szerint gyakorolt úr alom keresztény dogmájának nyugatias, voluntarisztikus megvalósítása. De fel kell ismerni, hogy valamivel több, mint száz évvel ezelőtt a tudomány és a technika (amelyek eddig teljesen különálló területek voltak) összefogásával olyan hatalmat adott az emberiségnek, amelyik fölött mára, az ökológiai hatások láttán elmondhatjuk, elvesztettük az uralmat ha pedig ez így van, akkor a kereszténységet hatalmas búnök terhelik." ${ }^{1}$

White 1967-es állásfoglalása óta sok árnyaltabb, az antropocentrizmus kárhoztatásán túlmutató történeti elemzés is született. Ezek közt akad olyan is, amely legfóképp a reformáció korában lezajlott szemléletbeli változásokat okolja korunk súlyos ökológiai bajaiért. A kortárs amerikai történész, Brad S. Gregory azt állítja, hogy a mai fogyasztói szemlélet gyökerei itt keresendők, mivelhogy azok a gyakorlatok, amelyeket egykor veszélyesnek és erkölcstelennek tekintettek, mert akadályozták az ember jól-létét és a közjó előmozdítását, egyszerre csak teljesen ellentétes előjelet kaptak, és az emberi boldogság, és a lehető legjobb társadalom elsődleges eszközévé léptek elő. „A reformáció korának nagy ellentmondása abban rejlik, hogy mind a protestánsok, mind a katolikusok azt segítették elő, amit elítéltek. A tanításbeli különbségek, a felekezeti hajthatatlanság és a kölcsönös ellenségesség természetsze-

\footnotetext{
${ }^{1}$ Lynn White Jr.: Ökológiai válságunk történeti gyökerei. In: Természet és szabadság. szerk.: Lányi András, Osiris, Bp., 2000. 27-35. o. Itt: 34. o. (The Historical Roots of our Ecological Crisis. In: Science 155., 1967, 1203-1207.)
} 
rúleg járult hozzá azoknak az intézményeknek, társadalmi viselkedésformáknak és ideológiáknak a kialakulásához, amelyek a nyugati kapitalizmust formálták. A keresztény erkölcsiség különböző megítélései eloldozták a piaci folyamatokat a hagyományos keresztény erkölcstől és létrehozták a piaci társadalmat. A felekezeti összeütközések elősegítették a nemzeti azonosulást a gazdaságban, hatalomban, prosperitásban mint a gondviselő Isten kegyelmének jelében, és így a felhalmozás politikailag és vallásilag is elismert kötelezettséggé vált. A keresztény értelemben vett jó mibenlétével kapcsolatos egyet nem értés akaratlanul is felgyorsította azt a folyamatot, amely a jó életet a javak bőségével azonosítja a jogok formális rendszerén belül." ${ }^{2}$ (Mindez az erkölcs egyfajta szubjektivizálásának felel meg: az állam megengedi polgárainak, hogy azt vegyenek, amit óhajtanak, ameddig az állam törvényeibe nem ütköznek.)

White történelmi és Gregory társadalomtörténeti alapozású érvelése hallatán tulajdonképpen nincs mit csodálkozni, ha a teológiában felmerül a feleletadás és az önigazolás szándéka, ezeken túlmenően azonban a teológia azzal az új helyzetből fakadó új határozott igénnyel is szembesül, hogy hatékony és plauzibilis útmutatással szolgáljon a környezetünkhöz való viszonyulás etikai kérdéseit illetően.

A környezetetikai érdeklődés jelentős növekedése megfigyelhető az e kérdésekkel foglalkozó teológiai szakirodalom utóbbi évtizedekben tapasztalható jelentős bővülésében és fragmentálódásában is. E helyt a tágabb környezetetikai kontextuson belül a táplálkozással kapcsolatos etikai kérdésekben megfogalmazott nézetekre és álláspontokra összpontosítunk. Az egyház és a teológia felelősségét, illetve válaszadási képességét firtató kérdések szükségessé teszik a keresztény étkezés hagyomány tüzetesebb vizsgálatát. Ha jelenségek alapos történeti feltárására e helyt nincs is

\footnotetext{
${ }^{2}$ Brad. S. Gregory: The Unintended Reformation: How a Religious Revolution Secularized Society. The Bellknap Press of Harvard University Press, 2012. Idézet: 273. o. (saját ford.)
}

lehetőség, a legfontosabb csomópontokra és fejlődési irányokra mégis érdemes rámutatni. Az ószövetségi étkezési hagyományok elsősorban a rituális tisztasági előírások és törvények mentén térképezhetők fel. A korai kereszténység eleinte részben követte ezeket a mintákat, később azonban, önértelmezése megszilárdulásával, elhatárolódott tőlük (jól illusztrálja ezt pl. a tisztátalan ételek fogyasztása körül kialakuló polémia). A korai kereszténység közös étkezései hellenisztikus formai keretek között valósultak meg, ünnepélyes, szakrális tartalmakat sem nélkülöző, hosszabb időtartamra kiterjedő társasági aktusok voltak. Ma az étkezés leginkább magányos cselekedet, nem előzik meg gondos, saját kezű előkészületek, mellékes időtöltés, ráadásul egyre jellemzőbb a közös tálból evés helyett az egyénre szabott diéták érvényesülése.

Hasonlóan fontos, ószövetségi alapokon nyugvó hagyomány a böjt és a töltekezés periódusainak meghatározott mintázatot követő váltakozása. Ez a ritmus is megszűnik, a böjtölés legfeljebb célelvǔ kúraként valósul meg, a természet által adott ritmus felismerhetetlenségével és a tradicionális szabályok elhalványulásával állandóan folytatható étkezés pedig elveszti közösségformáló és ünnepi jellegét.

A böjtölés kapcsán vetődik fel az aszkézis kérdése. Noha az evangéliumból is kiderül, hogy a kortársak nem tekintették különösebben aszketikus jelenségnek Jézust, a későbbi keresztény irodalomban mégis a nőtlen, vagyontalan és hontalan aszkéta mintaképévé vált. Látnunk kell azonban, hogy ez elsősorban egy olyan társadalmi identifikációs folyamat eredménye, amelyben a kereszténység a hellenista kultúrával és a zsidó hagyománnyal szemben határozta meg magát.

$\mathrm{Az}$ evéssel szemben megnyilvánuló, sokszor ellenséges attitűd gyökerei a Szentíráson kívül keresendők - az anyagi világ és az anyagi örömök tagadása ellentétben áll a teremtett világ jóságának és rendjének ószövetségi és újszövetségi hirdetésével egyaránt. Hátterében az a gnosztikus vonásokat mutató meggyőződés húzódik, amely a földi létet nem sokra becsüli, a 
világot rossznak, romlottnak tartja, az eljövendő élet és evilági lét közt nem feltételez anyagi jellegű kontinuitást. Vágyainak tárgya elsősorban a mennyek országába való bejutás, amely sokszor a meg nem rontott Édenbe való visszatérés képében jelentik meg. Ebben az interpretációban az evés egyenesen az eredendő bún elkövetésének eszköze lesz.

Elmondható tehát, hogy a korai keresztény étkezési és böjtölési szokások elsősorban a zsidó hagyományok fokozatos átalakulásaként értelmezhetők, de formálódásukra hatással voltak a környező egyéb vallások és filozófiai rendszerek is, mint pl. a gnoszticizmus vagy a hellenista vegetariánus hagyomány (orfikusok, püthagoreusok, neoplatonisták).

Az egyház megszilárdulásával és térnyerésével az étkezésben is új korszak nyílik: a sivatagi remeték a Krisztus-követést a testi vágyakról való minél teljesebb körű lemondásként kezdik értelmezni. Példájuk egyre többeket vonz, s a remeték egy idő után mintegy meghódítják a sivatagot, kialakulnak a korai szerzetesi közösségek. Ezekben visszaszorulnak az extrém önmegtartóztatás formái, hiszen a közösséget össze kell kovácsolni, valamint képesnek kell maradni a napi kétkezi munka ellátására. Létrejönnek az étkezést is szabályozó szerzetesrendi regulák, amelyek az engedelmességet helyezik előtérbe az aszketikus gyakorlatok terén folytatott versengéssel szemben. Az evéssel kapcsolatos előírások rendszerbe foglalása az intézményesülő egyház jellemzője lesz - az engedelmesség egyik látványos fokmérője az egyén táplálkozása.

A reformáció a képmutató böjtölést is szigorúan elítéli, s ezzel mintegy „kulináris felszabadulást” hoz magával. A mindaddig szigorú restrikciók alá eső húsfogyasztás mértékét innentől kezdve kizárólag a hús aktuális ára szabja meg, az erkölcsi megfontolások háttérbe szorulnak, a társadalom egészére nem vonatkoznak többé szigorú étkezési szabályrendszerek. Ilyesmivel (az étkezésre vonatkozó normatív szabályok önkéntes betartásával) a XX. század második feléig jellemző módon csak alacsony presztízsű, marginális-ellenkulturális társadalmi csoportoknál (pl. az állatvédőknél vagy a feminista mozgalomban) találkozunk. Mára a lassú változás vagy legalábbis a változás igényének jelei már jól felismerhetőek, főként az alternatív, a környezetre reflektáló életformák szélesedő elfogadottsága terén. Az ökológiai krízis a tudományos kérdések megválaszolásának szükségességén túl az egész Föld lakosságát érintő etikai választás elé is állít bennünket, mindennapi étkezéseink mikéntje közös jövőnket alakítja.

Hogyan teheti magát hasznossá a teológiai etika egy megfogalmazandó környezeti etikára nézve? A történeti tükör felmutatásán túl döntő momentumnak látszik, hogy hogyan képes a teológia rendszerbe illeszteni azt a napjaink tapasztalatai alapján körvonalazódó sejtést, hogy az emberi világ véges, a teremtés sebezhető, illetve hogy az ember jó eséllyel képes a teremtett világ elpusztítására. Perdöntő lehet, hogy egy ökoteológiai alapozású etika miként pozicionálja az embert a teremtett világban. A keresztény teológia hagyományosan és vállaltan antropocentrikus, ugyanakkor az ökoetikai elméletek egy jelentős része biocentrikusholisztikus jellegú, ill. antorpocentrizmusellenes. Az antropocentrizmus elvetése elméletileg minden élőlény egyenlőségét követeli, ugyanakkor az ember az, akinek meg kell teremtenie és fenn kell tartania az egyenlőséget, hiszen etikai-erkölcsi normák a többi létező számára aligha tűzhetők ki.

Tanulságos látni, miként kezelik e kérdést a környezeti etikával foglalkozó egyházi nyilatkozatok. A katolikus egyház álláspontja szerint megalkotható egy felelősen gondolkodó etika a relatív antorpocentrizmus, illetve egy ",hitben gyökerező" teocentrizmus talaján. Egyrészt elismeri, hogy minden létezőnek van önértéke, ugyanakkor fenn is tartja az ember ontológiai különbözőségének posztulátumát. A relatív antropocentrizmus láthatóan nem lépi át saját határait, és azt vallja, hogy lényegi változás nem állt be a teremtett világ állapotában, valamint az Isten-ember viszonyban, s ilyen módon a hagyományos egyházi megközelítés sem szorul alapvető változatásra, legfeljebb finomításra. A teremtett világ védelmének témájához kapcsolódó evangélikus egyházi nyilatkozatok pragma- 
tikusabb hangvételúek. Elismerik az egyház bűnrészességét (az egyéni helytelen fogyasztási szokások szintjén éppúgy, mint az ember természet feletti uralmát hangsúlyozó teológia alapozású környezeti etikák világlátásából is. Hangsúlyozzák, hogy a folyamatok kedvezőbb irányba tereléséhez a társadalom minden szintjén drasztikus átalakulásra van szükség, a „fogyasztáson és kizsákmányoláson alapuló modellek helyett pedig olyan modellekre, amelyek tisztelik a helyi gazdaságokat, az őslakosok kultúráját és spiritualitását, a Föld megújulóképességét, valamint más élőlények élethez való jogát." Az evangélikus nyilatkozatok mindegyike kiemeli az ökumenikus és vallásközi együttmúködés, a helyi szintű részvétel, valamint az oktatás és a tanulás fontosságát. $A z$ evangélikus egyház saját szerepét egyszerre látja a prófétai figyelemfelhívásban és a jobbí- szintjén, s egy új, „alázatos” teológia kialakítására hívnak fel, amely hajlandó és képes együttmúködni, illetve tanulni más tás szándékától vezérelt, körültekintő mérlegelésen alapuló tervezésen.

Milyen konzekvenciák vonhatók le az általános ökoetikai feladatkijelölésből a táplálkozásetikára nézve? A szerepvállalás lehetősége az alábbi részterületeken mutatkozik meg a legnyilvánvalóbban. Egyrészt a tanúságtétel, a figyelemfelhívás terén, másrészt az étkezéssel kapcsolatos, környezet és társadalom kívánalmait egyaránt mérlegelő keresztény hagyományok újraírása, újrahasznosítása terén, harmadrészt az egyes tudományágak problémaorientált megközelítésén felülemelkedő perspektíva lehetőségének felkínálása terén.

\section{A TÁPLÁLKOZÁSSAL KAPCSOLATOS TEOLÓGIAI ETIKAI TÁJÉKOZÓDÁST SEGÍTŐ SZAKIRODALOM:}

[1.] Grumett, David - Muers, Rachel (eds.): Eating and Believing: Interdisciplinary Perspectives on Vegetarianism and Theology. T\&T Clark, London, 2008.

[2.] Grumett, David - Muers, Rachel: Theology ont he Menu: Asceticism, Meat and Christian Diet. Routledge, London, 2010.

[3.] Wirzba, Norman: Food and Faith: A Theology of Eating. Cambridge University Press, 2011.

[4.] Young, Richard A.: Is God a Vegetarian? Christianity, Vegetarianism and Animal Rights. Carus Publishing Company, 1999. 